\title{
How (carbon) negative is direct air capture? Life cycle assessment of an industrial temperature- vacuum swing adsorption process
}

\author{
Sarah Deutz ${ }^{\mathrm{a}}$ and André Bardowa,b,c, ${ }^{\mathrm{a}}$ \\ aInstitute for Technical Thermodynamics, RWTH Aachen University, Aachen, Germany \\ bInstitute of Energy and Climate Research - Energy Systems Engineering (IEK-10), \\ Forschungszentrum Jülich GmbH, Jülich, Germany \\ ${ }^{\mathrm{c}}$ Energy \& Process Systems Engineering, ETH Zurich, Switzerland
}

\begin{abstract}
Current climate targets require negative emissions. Direct air capture (DAC) is a promising negative emission technology, but energy and materials demands lead to trade-offs with indirect emissions and other environmental impacts. Here, we show by Life Cycle Assessment (LCA) that the first commercial DAC plants in Hinwil and Hellisheiði can achieve negative emissions already today with carbon capture efficiencies of $85.4 \%$ and $93.1 \%$. Climate benefits of DAC, however, depend strongly on the energy source. When using low-carbon energy, as in Hellisheiði, adsorbent choice and plant construction become important with up to 45 and $15 \mathrm{gCO}_{2 \mathrm{e}}$ per $\mathrm{kg} \mathrm{CO}_{2}$ captured, respectively. Large-scale deployment of DAC for $1 \%$ of the global annual $\mathrm{CO}_{2}$ emissions would not be limited by material and energy availability. Other environmental impacts would increase by less than $0.057 \%$. Energy source and efficiency are essential for DAC to enable both negative emissions and low-carbon fuels.
\end{abstract}

Corresponding author

*E-mail address: abardow@ethz.ch

Preprint submitted to ChemRxiv August 20, 2020 


\section{Main text}

Fossil energy is still the basis of most societies, which led to $36.8 \mathrm{Gt} \mathrm{CO}_{2 \mathrm{e}}$ of greenhouse gas (GHG) emissions in 2019. ${ }^{1,2}$ Moving from fossil energy to renewable energy will reduce GHG emissions. However, there is broad scientific consensus that the target of the 2015 COP21 Paris climate agreement ${ }^{3}$ requires not only a massive reduction in $\mathrm{GHG}$ emissions but even up to $30 \mathrm{Gt} / \mathrm{a}$ of negative emissions. ${ }^{4-9}$

Negative emissions could be provided by direct air capture (DAC) of $\mathrm{CO}_{2}$ with subsequent storage for carbon dioxide removal (CDR). ${ }^{10-12}$ Captured $\mathrm{CO}_{2}$ can be stored geologically or via mineralization. ${ }^{13,14}$ However, DAC not only allows us to remove GHG emissions from our past use of fossil fuels. DAC also enables future fuels with a closed carbon cycle: The captured $\mathrm{CO}_{2}$ could serve as a carbon feedstock for fuels ${ }^{15-20}$, and also other value-added products like chemicals ${ }^{21-24}$ and building materials ${ }^{25-27}$ via carbon capture and utilization (CCU).

The most developed DAC concepts separate $\mathrm{CO}_{2}$ from the air by either ab- or adsorption. ${ }^{28-30}$ DAC based on absorption typically uses aqueous hydroxy sorbents like alkali and alkali-earth hydroxides. In contrast, DAC based on adsorption can employ a wide range of solid sorbents. For example, alkali carbonates, ${ }^{31,32}$ amines supported on oxides, ${ }^{33,34}$ solid organic materials $^{33,35-37}$, and metal-organic frameworks (MOFs) ${ }^{33,38}$. Absorption by aqueous sorbents allows for low costs and continuous operation, ${ }^{39}$ but leads to high water loss. ${ }^{40}$ Furthermore, sorbent regeneration requires high temperatures. ${ }^{30,41}$ In contrast, DAC by adsorption can operate at low regeneration temperatures $\left(<100^{\circ} \mathrm{C}\right) .{ }^{30,39,42,43}$ The first commercial DAC system employs solid adsorbents in cyclic temperature-vacuum swing adsorption. ${ }^{44-46}$

While DAC removes $\mathrm{CO}_{2}$ directly from the atmosphere, the potential climate benefits of DAC are partly offset by indirect environmental impacts due to the supply of energy and materials. So far, a detailed assessment of this trade-off is only available for GHG emissions for a DAC process with aqueous hydroxy sorbents, where high-temperature heat is usually obtained from natural gas, and the resulting $\mathrm{CO}_{2}$ emissions are re-captured. ${ }^{20,40}$ Available assessments for adsorption-based DAC systems consider energy requirements but use proxy data for plant construction and adsorbent. ${ }^{47,48}$ Thus, a comprehensive environmental assessment is missing for adsorption-based DAC but urgently needed to establish the role of DAC in climate-change mitigation. 49 
Herein, we comprehensively evaluate the environmental impacts of adsorption-based DAC using the method Life Cycle Assessment (LCA). ${ }^{50,51}$ Temperature-vacuum swing adsorption is studied based on data from the first commercial DAC plants. Industrial data for the construction and the operation of the DAC plant is provided by the company Climeworks. Six adsorbent materials ${ }^{29,41,52}$ are analyzed, supported by Climeworks regarding the potential use in industrial plants.

Our analysis shows that capturing $\mathrm{CO}_{2}$ by DAC leads to negative emissions even today if the captured $\mathrm{CO}_{2}$ is permanently stored, and towards carbon-neutral fuels, if the captured $\mathrm{CO}_{2}$ is used as renewable carbon feedstock. Climate impact reductions depend strongly on the energy supply, while the adsorbent and infrastructure become important when low-carbon energy is used. Even large-scale deployment of DAC, capturing $1 \% 53$ of the global annual $\mathrm{CO}_{2}$ emissions, is neither constrained by material and energy supply for plant construction and operation, nor would it lead to significant trade-offs in other environmental impact categories (increases $<0.057 \%$ ).

\section{Results}

\section{The carbon footprint of captured $\mathrm{CO}_{2}$ from cradle-to-gate}

Our LCA results show that the first industrial DAC plants can already provide $\mathrm{CO}_{2}$ with a negative carbon footprint from cradle-to-gate today: if waste heat is available, or if the electricity to drive the heat pump has a carbon footprint of Italy or cleaner (Figure 1). For a future scenario that employs performance targets for the DAC plant, the carbon footprints are negative from cradle-to-gate for the full range of considered electricity grid mixes (see Methods).

The carbon footprint for the captured $\mathrm{CO}_{2}$ depends linearly on the carbon footprint of electricity supply (Figure 1). The carbon capture efficiency is the ratio of avoided $\mathrm{CO}_{2}$ emissions from cradle-to-gate to $\mathrm{CO}_{2}$ captured (see Methods) and reaches almost $100 \%$ for wind power. Today, wind power has a carbon capture efficiency of $95.1-96.4 \%$ depending on the heat source. For the future scenario, the carbon capture efficiency for wind power ranges between $96.0-96.6 \%$. The carbon footprint of captured $\mathrm{CO}_{2}$ depends less strongly on the electricity grid mix if waste heat can be used since heating via heat pumps require more electricity.

To be specific for the actual DAC plants built today, we consider the local energy supply for the two locations in which Climeworks is currently operating: Hellisheiði (Iceland) and Hinwil 
(Switzerland). The DAC plant in Hellisheiði uses geothermal energy, and the plant in Hinwil uses electricity and waste heat from municipal waste incineration. Today, the DAC plants in Hellisheiði and Hinwil could reach a carbon capture efficiency of $93.1 \%$ and $85.4 \%$, respectively. In the scenario representing the future, the carbon capture efficiency increases to $95.0 \%$ and $88.8 \%$. However, municipal waste incineration in Hinwil is a multifunctional process. We analyzed that carbon capture efficiencies could range from $46.0-96.5 \%$ and $60.7-96.7 \%$ depending on the allocation between waste disposal and the co-produced electricity today and in the future scenario, respectively. The full range of all environmental impacts for Hinwil and more data are given in the Supplementary Note 3 and 9.

Although energy requirements mainly determine the carbon footprint, the carbon capture efficiency does not reach $100 \%$, even if assuming a burden-free electricity supply (i.e., surplus power; Figure 1). The construction of the DAC plant and the adsorbent production reduce the carbon capture efficiency by $0.6 \%$ and $2.3 \%$, respectively. Thus, the contribution of DAC plant and adsorbents becomes only relevant for clean electricity mixes such as in Hellisheiði, where the adsorbent and the DAC plant contribute up to $59 \%$ to the carbon footprint of the captured $\mathrm{CO}_{2}$. We, therefore, discuss adsorbent choice and plant construction in more detail next. Carbon capture efficiencies and other environmental impacts for the considered grid mixes are given in the Supplementary Note 9. 


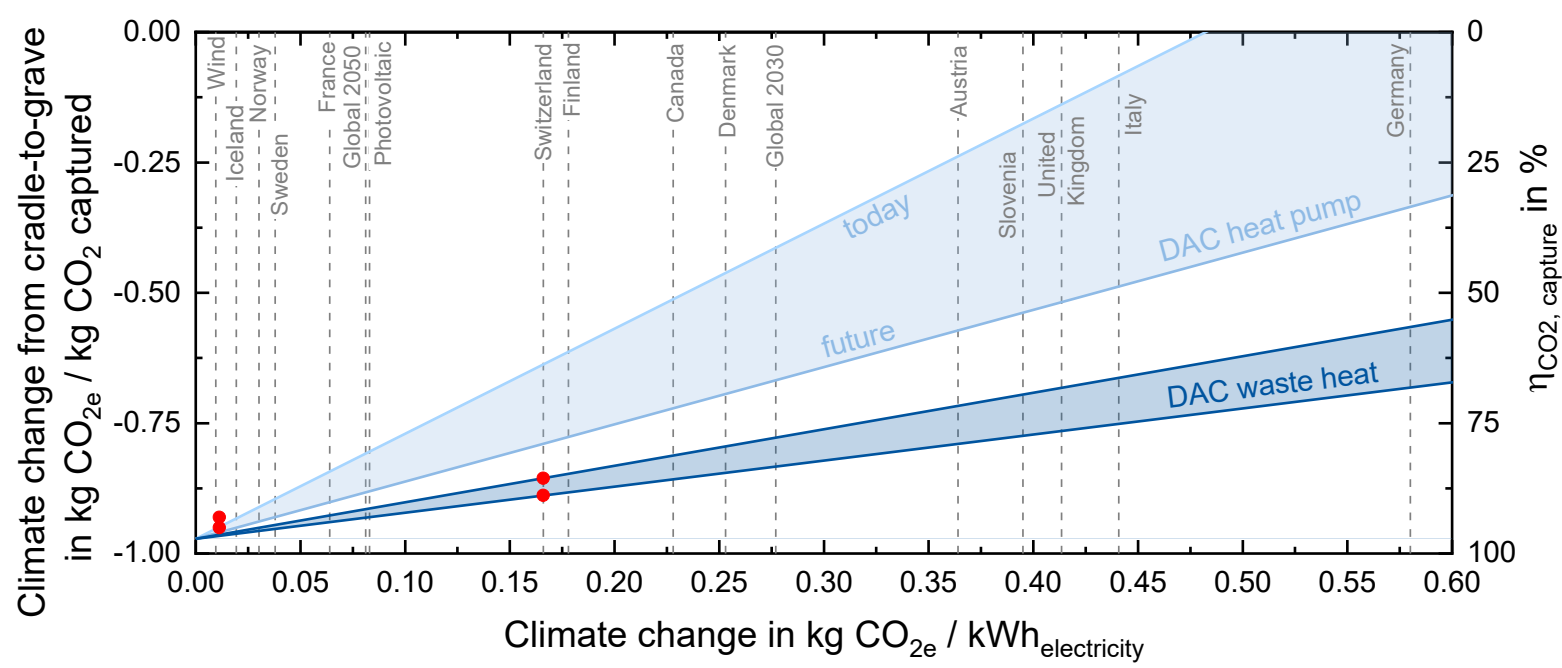

Figure 1: Carbon footprint per $\mathrm{kg} \mathrm{CO}$ captured (left y-axis) over the carbon footprint of electricity supply per kWh (x-axis) from cradle-to-gate. Right y-axis: carbon capture efficiency (see Methods, Eq. 1). The areas are spanned by the energy scenarios for today (top line) and the future (bottom line; see Methods). Heat is provided via a heat pump system (coefficient of performance $=2.51$ ) or waste heat (see Methods). The $\mathrm{CO}_{2}$ capture plant has a capacity of $4 \mathrm{kt} \mathrm{CO} / \mathrm{a}$ (see Methods) and an adsorbent consumption of $7.5 \mathrm{~g}$ adsorbent (amine on silica; see Supplementary Note 1) per $\mathrm{kg} \mathrm{CO}_{2}$ captured. Red dots mark local energy supply conditions for the two locations in which Climeworks is currently operating: Hellisheiði (Iceland) and Hinwil (Switzerland; see Methods). Heat and electricity for the plant in Hellisheiði are supplied by geothermal energy. The plant in Hinwil uses electricity and waste heat from an incineration plant. Note that the cradleto-gate system boundary excludes the application of $\mathrm{CO}_{2}$, determining if the $\mathrm{CO}_{2}$ is re-emitted or permanently removed from the atmosphere.

\section{Adsorbents}

For the six considered adsorbents, the carbon footprint varies between 10 and $46 \mathrm{~g} \mathrm{CO}_{2 \mathrm{e}}$ per $\mathrm{kgCO}_{2}$ captured (Figure 2; see Supplementary Note 1 for detailed information). The production contributes 60 - $91 \%$ much more to the total carbon footprint of the adsorbent than the end-of-life. The lowest carbon footprint is achieved by amine on alumina, potassium carbonate on silica, and potassium carbonate on activated carbon (Figure 2). However, we believe that the differences in the carbon footprint of the adsorbents are minor, considering the considerable uncertainty in the Life Cycle Inventories ( $\mathrm{LCl}$ ) of the adsorbents in the early stages of development. Overall, the carbon footprint is low for all considered adsorbents. 


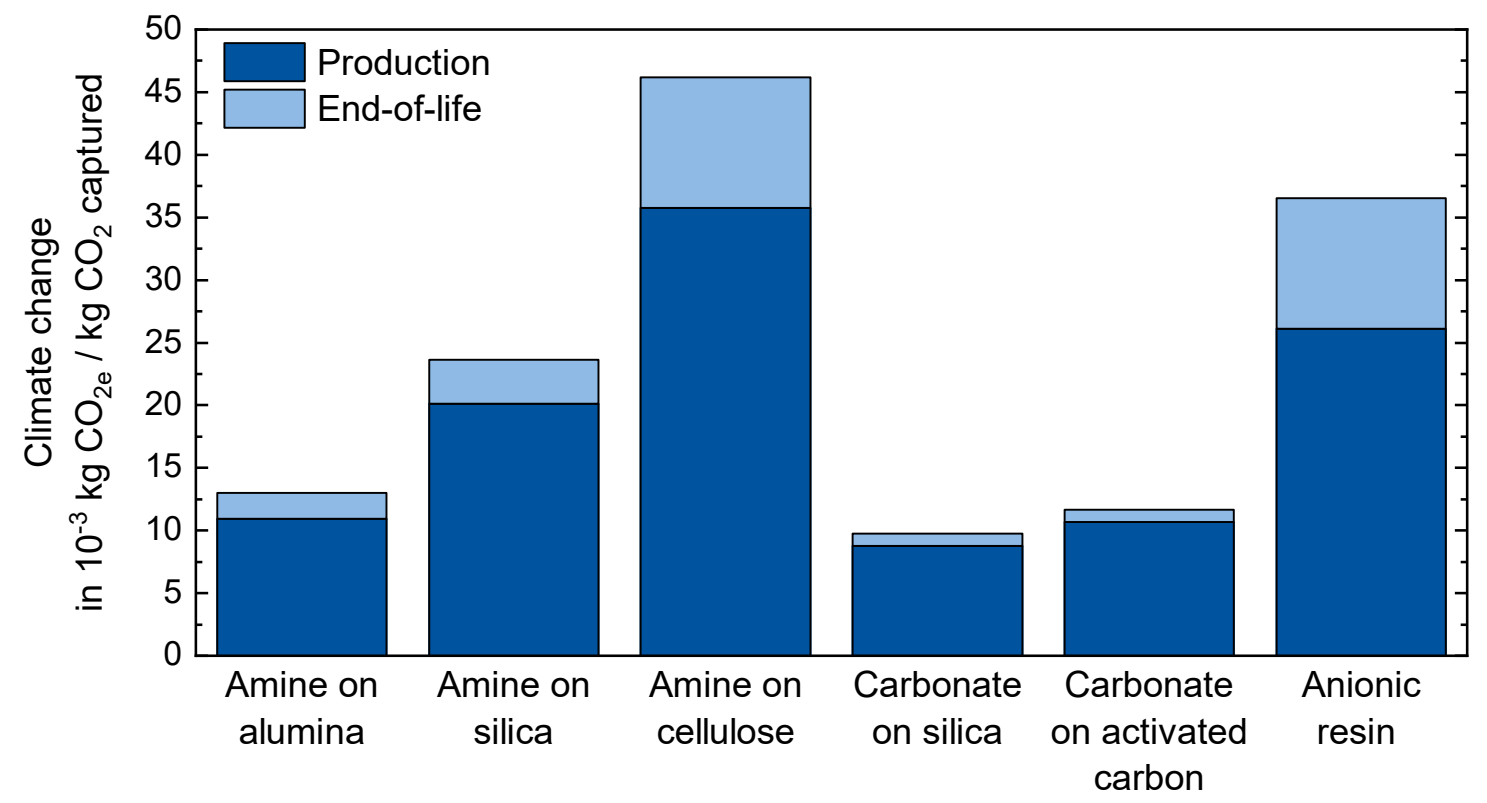

Figure 2: Carbon footprint of the considered adsorbents from cradle-to-gate (production) and from cradleto-grave (including end-of-life) in $\mathrm{kg} \mathrm{CO}_{2}$ per $\mathrm{kg} \mathrm{CO}$ captured. Adsorbent consumption is assumed to be $7.5 \mathrm{~g}$ adsorbent per $\mathrm{kg} \mathrm{CO} 2$ captured.

No adsorbent performs best in all 16 considered environmental impact categories leading to trade-offs in selecting the adsorbent (Table 1; for details, see Supplementary Figure 1-15 and Table 23). On average, amine on alumina performs environmentally best, but the alumina support production leads to higher impacts in human toxicity, cancer. This environmental impact category, however, has medium to high uncertainty (quality level II/III; see Methods). Amine on silica depletes more mineral and metal resources (quality level III) due to silica production. The carbonate-based adsorbents perform similar to amine on alumina, but substantially increase eutrophication of freshwater (quality level II) through potassium carbonate production. The two adsorbents amine on cellulose and anionic resin show higher environmental impacts than all other adsorbents: Amine on cellulose has a comparable high impact in land use due to cellulose being the only bio-based material used; anionic resin production is modeled by a generic process that leads to a massive impact in ozone depletion due to heuristics in the Life Cycle Inventory ( $\mathrm{LCl}$; see Supplementary Note 1 and 6). In the authors' view, the heuristic does not lead to a realistic result in this case. Therefore, we do not report the ozone layer depletion impact attributed to the anionic resin. 
Table 1: Relative difference of environmental impacts for the considered adsorbents compared to amine on silica. A positive change (green) indicates an improvement in the environmental impact category compared to the adsorbent amine on silica. In contrast, a negative change represents a deterioration and is shown in red. The environmental impacts are classified according to their quality level as given by the European Commission's Joint Research Centre (see Methods)..$^{54,55}$ All details are documented in the Supplementary Figure 1-15 and Supplementary Table 23. * Anionic resin leads to a massive impact in ozone layer depletion. In the authors' view, this impact in ozone layer depletion does not lead to a realistic result. We, therefore, do not report the ozone layer depletion for the anionic resin. ** Cellulose is the only bio-based material used; thus, amine on cellulose shows a high impact on land use.

\begin{tabular}{|c|c|c|c|c|c|c|}
\hline $\begin{array}{l}\text { Quality } \\
\text { level }\end{array}$ & Environmental impact & $\begin{array}{l}\text { Amine on } \\
\text { alumina }\end{array}$ & $\begin{array}{l}\text { Amine on } \\
\text { cellulose }\end{array}$ & $\begin{array}{l}\text { Carbonate } \\
\text { on silica }\end{array}$ & $\begin{array}{c}\text { Carbonate } \\
\text { on silica }\end{array}$ & $\begin{array}{l}\text { Anionic } \\
\text { resin }\end{array}$ \\
\hline \multirow{3}{*}{ I } & Climate change & 45.0 & -95.3 & 58.8 & 50.8 & -54.4 \\
\hline & Ozone depletion & 47.1 & 1.2 & 13.9 & 20.6 & * \\
\hline & Particulate matter & 45.0 & -31.5 & 51.5 & 49.0 & 11.1 \\
\hline \multirow{6}{*}{ II } & $\begin{array}{c}\text { Acidification, terrestrial and } \\
\text { freshwater }\end{array}$ & 46.0 & 1.2 & 50.8 & 44.0 & 4.9 \\
\hline & Eutrophication, freshwater & 45.0 & 25.6 & -66.0 & -54.2 & -133.5 \\
\hline & Eutrophication, marine & 48.0 & 1.6 & 71.1 & 62.8 & 8.6 \\
\hline & Eutrophication, terrestrial & 45.2 & -48.9 & 44.8 & 21.4 & -16.9 \\
\hline & lonizing radiation & 40.9 & 15.2 & 66.6 & 39.7 & 60.3 \\
\hline & Photochemical ozone formation & 44.7 & -43.1 & 50.4 & 28.2 & -28.9 \\
\hline \multirow{3}{*}{ II/III } & Human toxicity, cancer & -43.8 & -1.2 & 22.2 & 28.7 & -144.3 \\
\hline & Human toxicity, non-cancer & 18.5 & -15.4 & -4.9 & -3.4 & -93.7 \\
\hline & Ecotoxicity, freshwater & 22.4 & 10.2 & 36.0 & 41.0 & -89.7 \\
\hline \multirow{4}{*}{ III } & Land use & 39.1 & $-2210.6^{* *}$ & 36.9 & 1.5 & 44.4 \\
\hline & Water scarcity & 48.5 & -78.7 & 54.1 & 50.8 & -23.2 \\
\hline & Resource depletion, energy & 46.2 & -53.0 & 68.2 & 59.3 & -0.8 \\
\hline & $\begin{array}{l}\text { Resource depletion, mineral and } \\
\text { metals }\end{array}$ & 51.5 & 47.8 & -60.3 & -18.7 & -106.8 \\
\hline
\end{tabular}

Due to the uncertainties in the $\mathrm{LCl}$ data, we provide a sensitivity study of the adsorbents exploring worst-case scenarios (see Supplementary Table 24). For the amine-based adsorbents, the sensitivity study shows that environmental impacts could increase by factors between 1.0 and 2.8. For the anionic resin, the potential increase compared to the generic process is much higher, with factors between 3.6 and 4.6. The results for the adsorbents demonstrate the influence of the production and raw material provision on their environmental impacts. Our sensitivity study highlights the importance of a comprehensive environmental assessment when developing new sorbents and the need for insights from the adsorbent suppliers. In all other parts of the main text, we consider amine on silica as adsorbent due to its average performance from an environmental viewpoint. 


\section{Plant construction}

The construction of a DAC plant with a capacity of $4 \mathrm{kt} \mathrm{CO}_{2} / \mathrm{a}$ has a low carbon footprint of $15 \mathrm{~g} \mathrm{CO}_{2 \mathrm{e}}$ per $\mathrm{kg} \mathrm{CO}_{2}$ captured - even without metal recycling (Figure 3; see Supplementary Note 2). Recycling of metals would be expected for a DAC application and reduces the carbon footprint of construction to $6 \mathrm{~g} \mathrm{CO}_{2 \mathrm{e}}$ per $\mathrm{kg} \mathrm{CO}_{2}$ captured (Figure 3). With metal recycling, the carbon footprint of the DAC plant is mainly due to the foundation and hall $(74 \%)$. The remaining emissions are caused by the container collectors (13\%), the process unit (12\%), and the spare parts contribute less than $1 \%$.

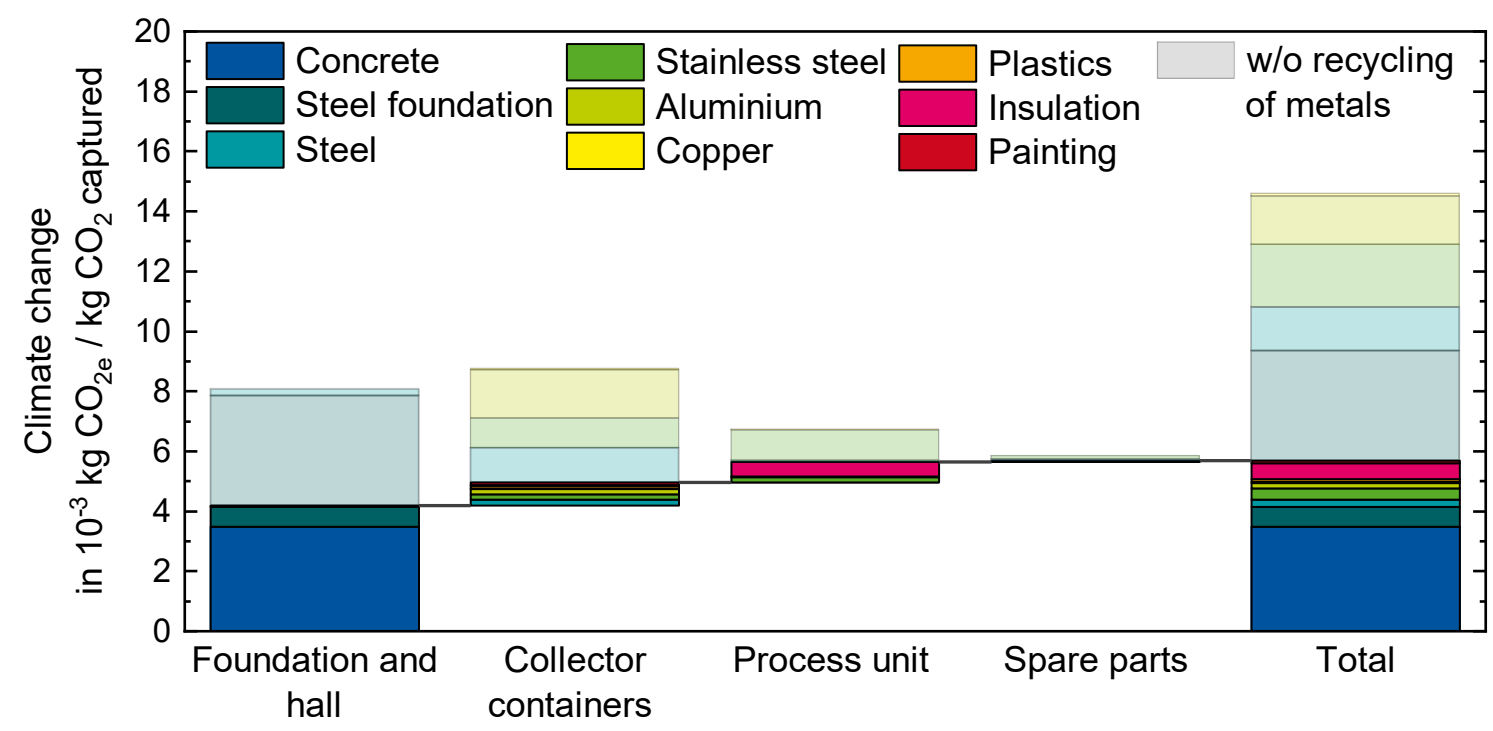

Figure 3: Carbon footprint breakdown analysis for the construction of the DAC with a capacity of 4 kt $\mathrm{CO}_{2} / \mathrm{a}$ (see Methods) in $\mathrm{kg} \mathrm{CO}_{2 \mathrm{e}}$ per $\mathrm{kg} \mathrm{CO}$ captured. Metals are recycled while all other materials are sent to waste treatment and disposal. The transparent bars represent climate change impacts of the DAC plant without the recycling of metals.

For the other environmental impacts, steel production for the foundation contributes 63 - $94 \%$ to eutrophication, freshwater; human toxicity, cancer and ecotoxicity, freshwater (quality level II-II/III). Resource depletion, mineral and metal (quality level III) is mainly caused by copper production (87\%). For all other environmental impacts, concrete contributes $32-70 \%$ and the foundation steel 11 - $39 \%$. Other materials contributions reach up to $18 \%$ for stainless steel, $16 \%$ for insulation, $12 \%$ for aluminum, $5 \%$ for steel, $4 \%$ for both copper and painting, and $2 \%$ for plastics. (for details see Supplementary Note 8). 


\section{Carbon footprint of captured $\mathrm{CO}_{2}$ from cradle-to-grave}

Over the entire life cycle, DAC can achieve negative emissions if combined with subsequent storage to perform carbon dioxide removal (CDR; Figure 4, for detailed information, see Methods). CDR would lead to negative emissions with all electricity grid mixes in the scenarios for the future. In the scenario for today, negative emissions are reached for all considered electricity grid mixes with waste heat. In contrast, today, CDR with a heat pump requires electricity grid mixes as clean as in Italy or cleaner to achieve negative emissions.

Emissions are most negative with wind power as electricity source. The carbon removal efficiency is the ratio of the avoided $\mathrm{CO}_{2}$ emissions by $\mathrm{CDR}$ to the $\mathrm{CO}_{2}$ captured (see Methods) and reaches $95.1 \%$ and $96.5 \%$ depending on the heat source and scenario (today and future). Due to the low impacts from storage, the carbon removal efficiency is close to the carbon capture efficiency. Details are presented in the Supplementary Note 9.

In contrast to $\mathrm{CDR}$, the use of $\mathrm{CO}_{2}$ from DAC to produce synthetic fuels can at best be carbon neutral (Figure 4, for detailed information, see Methods). Here, the use of $\mathrm{CO}_{2}$ for synthetic fuels is illustrated by methanation of $\mathrm{CO}_{2}$ with $\mathrm{H}_{2}$ to synthetic methane $\left(\mathrm{CH}_{4}\right)$ via the Sabatier reaction. ${ }^{56}$ Synthetic methane can reduce climate impacts compared to fossil-based methane for electricity grid mixes with a lower climate impact than the current grid mix in Switzerland, such as in Iceland, Norway, Sweden, and France, and projected by the global forecast for 2050 (carbon-reducing; Figure 4). For grid mixes with a higher carbon footprint than Switzerland, DAC for synthetic methane production increases the carbon footprint compared to fossil-based methane (carbon increasing; Figure 4). Overall, DAC for fuels can contribute to closing the carbon cycle and reducing $\mathrm{CO}_{2 \mathrm{e}}$ emissions if low carbon energy is employed to reach carbon neutrality over the entire life cycle. 


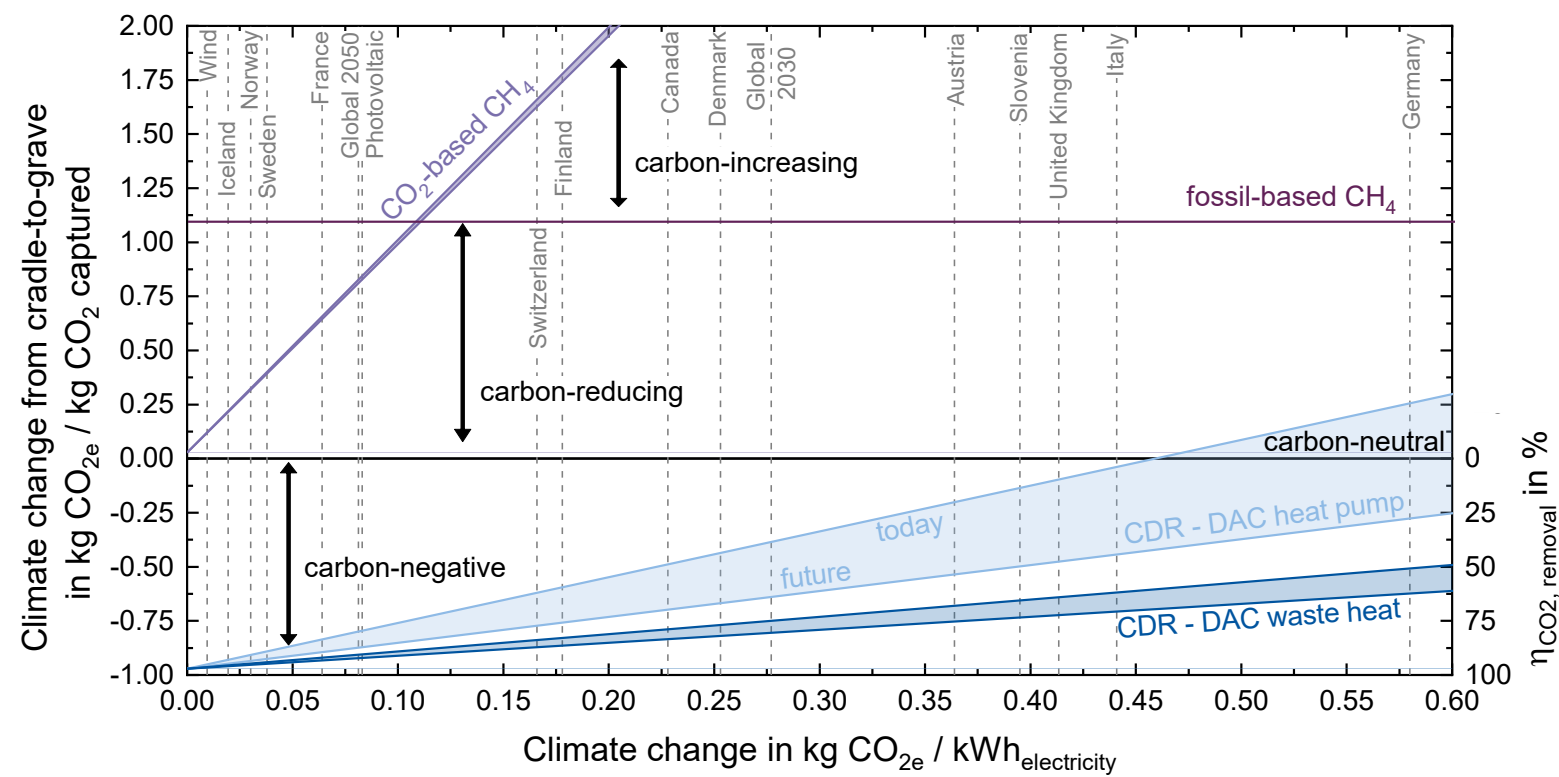

Figure 4: Carbon footprint per $\mathrm{kg} \mathrm{CO}_{2}$ captured (left y-axis) over the carbon footprint of the electricity supply per kWh (x-axis) from cradle-to-grave. Right y-axis: carbon removal efficiency (Methods Eq. 2). The areas are spanned by the today (top line) and future (bottom line) scenario for energy supply (see Methods). Heat is provided via a heat pump system and waste heat, except for $\mathrm{CO}_{2}$-based fuel $\left(\mathrm{CH}_{4}\right)$, where heat from methanation is used for the DAC system (see Methods and Supplementary Note 4). Both $\mathrm{CO}_{2}$-based and fossil-based methane includes the subsequent combustion to cover the entire life cycle but neglects the use phase, which would be identical. The $\mathrm{CO}_{2}$ capture plant has a capacity of $4 \mathrm{kt} \mathrm{CO}_{2} / \mathrm{a}$ (see Methods) and an adsorbent consumption of $\mathbf{7 . 5} \mathrm{g}$ adsorbent (amine on silica; see Supplementary Note 1) per $\mathrm{kg} \mathrm{\textrm {CO } _ { 2 }}$ captured.

\section{Discussion}

Our results show that DAC combined with storage has the potential for negative emissions already today. However, a substantial contribution to climate change mitigation requires the rapid and massive deployment of DAC. Capturing $1 \%$ of the global annual $\mathrm{CO}_{2}$ emissions in 2018 will require 3,683 DAC plants with a capacity of 100,000 t/a per plant (see Supplementary Note 2). Based on our analysis, we do not expect that this scale-up will be limited by material and energy requirements. The corresponding demands for materials and energy correspond to low shares of their global markets with shares below $0.1 \%$ for all materials (except the adsorbent): concrete $0.048 \%$, steel $0.003 \%$, stainless steel $0.031 \%$, aluminum $0.004 \%$, copper $0.005 \%$ and plastics $0.084 \%$ (Figure 5, see Supplementary Note 5). For the adsorbent (amine on silica), the future plant is expected to reduce adsorbent consumption to $3 \mathrm{~g}$ adsorbent per $\mathrm{kg} \mathrm{CO}_{2}$. The required global market share of both the amine and silica would then correspond to $3.01 \%$, mainly due to the production of polyethylenimine, suggesting that an expansion of the actual production capacity would be required for the application of DAC at large scale. The large-scale DAC scenario would need an additional $1.31 \%$ of the expected total electricity generation in 2030 , mainly to drive the heat pump. Subsequent storage of $\mathrm{CO}_{2}$ 
in geological formations for CDR would require an additional $0.12 \%$ of the global electricity generation.

For such large-scale deployment of DAC, the area occupied by the 3,683 DAC plants would be about $29 \mathrm{~km}^{2}$. Using wind power solely to generate the electricity for the DAC system and subsequent storage would require an additional $445 \mathrm{~km}^{2}$, using a global average value for the area requirement of wind power ${ }^{57}$. Using electricity via photovoltaics would increase the area needed by one order of magnitude to $4450 \mathrm{~km}^{2}$. Still, bioenergy and subsequent storage are estimated to require much larger areas of $100,000-150,000 \mathrm{~km}^{2}$ to grow bioenergy crops. ${ }^{58}$ For further information, please refer to Supplementary Note 6.

These materials demands are particularly encouraging since the considered large-scale deployment for capturing $1 \%$ of the global $\mathrm{CO}_{2}$ emissions is still much smaller than potentially required negative emissions of up to $30 \mathrm{Gt} / \mathrm{a}$. Even then, most material demands would be reasonable. The electricity demand for DAC, however, would exceed the global supply for 2030.

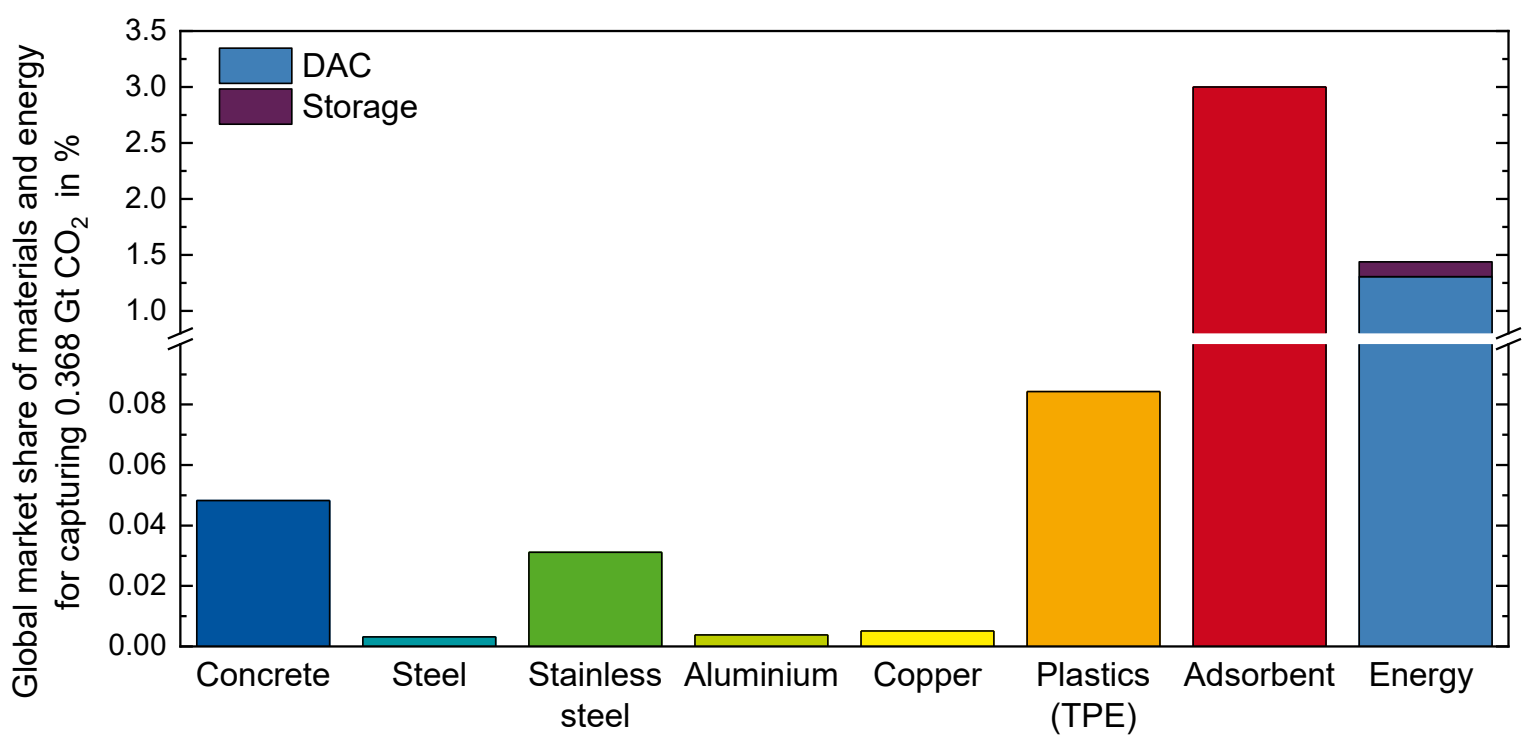

Figure 5: Relative amounts of the required materials and energy for capturing $1 \%$ of the annual global $\mathrm{CO}_{2}$ emissions $\left(0.368 \mathrm{Gt} \mathrm{CO}_{2} / \mathrm{a}\right)$ compared to the global market size of the materials and generated electricity in 2030 (see Supplementary Note 5). Results are shown for the DAC system (heat by heat pump system) from cradle-to-gate and from cradle-to-grave, including carbon dioxide removal (CDR). $\mathrm{CO}_{2}$ capture unit is based on the future plant with an adsorbent consumption of $3 \mathrm{~g}$ adsorbent (amine on silica; see Supplementary Note 1) per $\mathrm{kg} \mathrm{CO}_{2}$ captured. For plastics, we assume the market size of thermoplastic elastomers (TPE), and for the adsorbent amine on silica, we consider the market size of amorphous synthetic silica production and polyethylenimine (PEI). 
Capturing $1 \%\left(0.368 \mathrm{Gt} \mathrm{CO}_{2} / \mathrm{a}\right)$ of the global annual emissions and subsequent storage leads to a removal of $0.360 \mathrm{Gt} \mathrm{CO}_{2} / \mathrm{a}$ when supplied by wind power (carbon removal efficiency of $97.6 \%$ ). The benefit of capturing $1 \%$ global $\mathrm{CO}_{2 \mathrm{e}}$ emissions has to be weighed against the increase in other environmental impacts (Figure 6). This increase, however, is much smaller than $1 \%$ for most environmental impacts: The largest relative increase is $0.057 \%$ for human toxicity, cancer, which is an impact category with very high uncertainty (quality level II/III). The other impacts increase mainly due to the adsorbent $(4.8-84.3 \%)$ and electricity supply via wind power ( 0 - 92.1\%). However, all environmental impacts increase even less by using other adsorbents (cf. Table 1), which shows that a careful choice of adsorbent is indispensable for large-scale deployment of DAC.

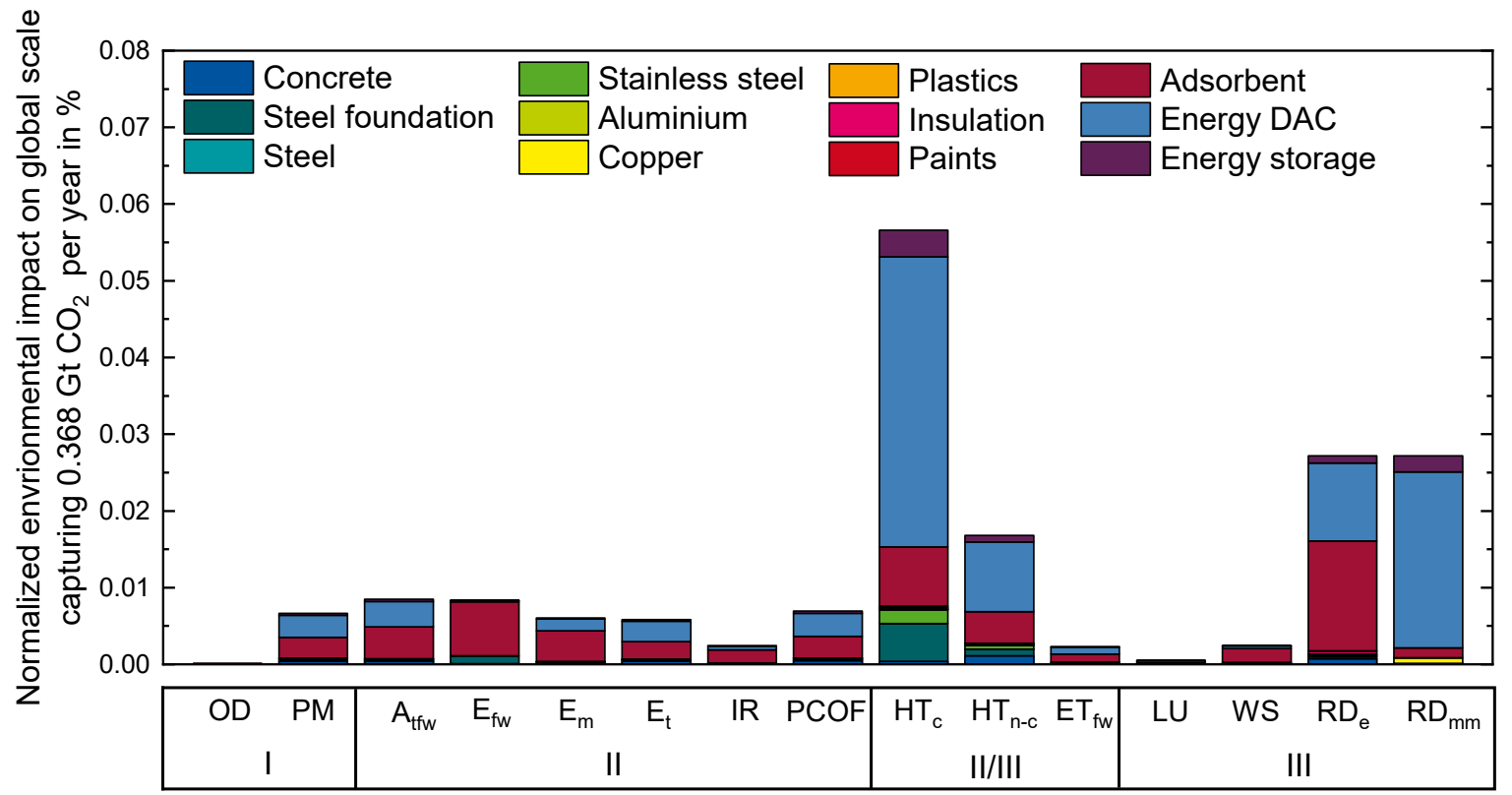

Figure 6: Normalized environmental impacts for capturing $1 \%$ of the annual global $\mathrm{CO}_{2}$ emissions $(0.368 \mathrm{Gt} \mathrm{CO} / \mathrm{a})$ from cradle-to-gate and from cradle-to-grave including carbon dioxide removal (CDR). The considered environmental impacts: ozone depletion (OD), particulate matter (PM), acidification, terrestrial and freshwater $\left(A_{t f w}\right)$, eutrophication freshwater $\left(E_{f w}\right)$, eutrophication, terrestrial $\left(E_{t}\right)$ and marine $\left(E_{m}\right)$, ionizing radiation (IR), photochemical ozone formation (PCOF), human toxicity, cancer ( $\left.\mathrm{HT}_{c}\right)$ and noncancer $\left(H T_{n c}\right)$, ecotoxicity freshwater $\left(E T_{f w}\right)$, land use (LD), water scarcity (WS), resource depletion $\left(R D_{e}\right)$ and mineral and metal $\left(R D_{\mathrm{mm}}\right) . \mathrm{CO}_{2}$ capture unit is based on the future plant with an adsorbent consumption of $3 \mathrm{~g}$ adsorbent (amine on silica). Electricity is provided by wind power as best-case and heat by a heat pump system in the future scenario. The impacts are normalized by the European Commission's Joint Research Centre reference values. ${ }^{59}$

Our environmental analysis of DAC via temperature-vacuum swing adsorption system shows that the contribution of DAC to climate change mitigation depends on the subsequent utilization of $\mathrm{CO}_{2}$ : permanent storage leads to negative emissions already in many countries today; whereas the usage as renewable carbon feedstock for fuels could reach carbon neutrality over the entire life cycle but requires low-carbon electricity. Potential climate impact reductions depend strongly on the energy supply highlighting the importance of matching large-scale DAC 
operation to renewable energy pathways. When using low-carbon energy, the adsorbent choice and plant construction become more important for climate change mitigation and other environmental impacts. A sensitivity study, however, shows large uncertainties of up to a factor 4.66 in the data for the adsorbents today, which emphasizes the need for insights from adsorbent developers. Overall, our results show the potential for DAC as negative emission technology and provide the basis for a sound integration of DAC into research agendas, integrated assessment models, future policy frameworks, and climate mitigation strategies.

\section{Methods}

\section{Goal and scope of the study}

LCA is a holistic methodology for the environmental assessment of products and services, taking into account their entire life cycle. ${ }^{50,60}$ The life cycle contains all activities from cradle-tograve: the extraction of raw materials, transportation, production, and product use to recycling and final disposal of waste. All flows of energy and materials exchanged with the environment throughout the life cycle are collected and interpreted regarding their environmental impacts. Various environmental impact categories such as climate change and acidification are usually considered. A detailed description of the LCA methodology is provided by ISO $14040 / 14044 . .^{50,51}$ In the following, we provide the process description for $\mathrm{CO}_{2}$ capture from air via temperature-vacuum swing adsorption, the goal and scope definition, and the Life Cycle Inventory (LCI) of our LCA study.

\section{Process description}

The considered Climeworks plant consists of several $\mathrm{CO}_{2}$ collectors, heat exchangers, a vacuum pump, and a water separation system (Figure 7). The $\mathrm{CO}_{2}$ collector is the reactor in which the adsorbent is placed, and where the adsorption/desorption process occurs. Adsorption-desorption steps are conducted in semi-batch operation as a cyclic process. The adsorption process can take place in several $\mathrm{CO}_{2}$ collectors, while other $\mathrm{CO}_{2}$ collectors are in desorption mode (Figure 8). 


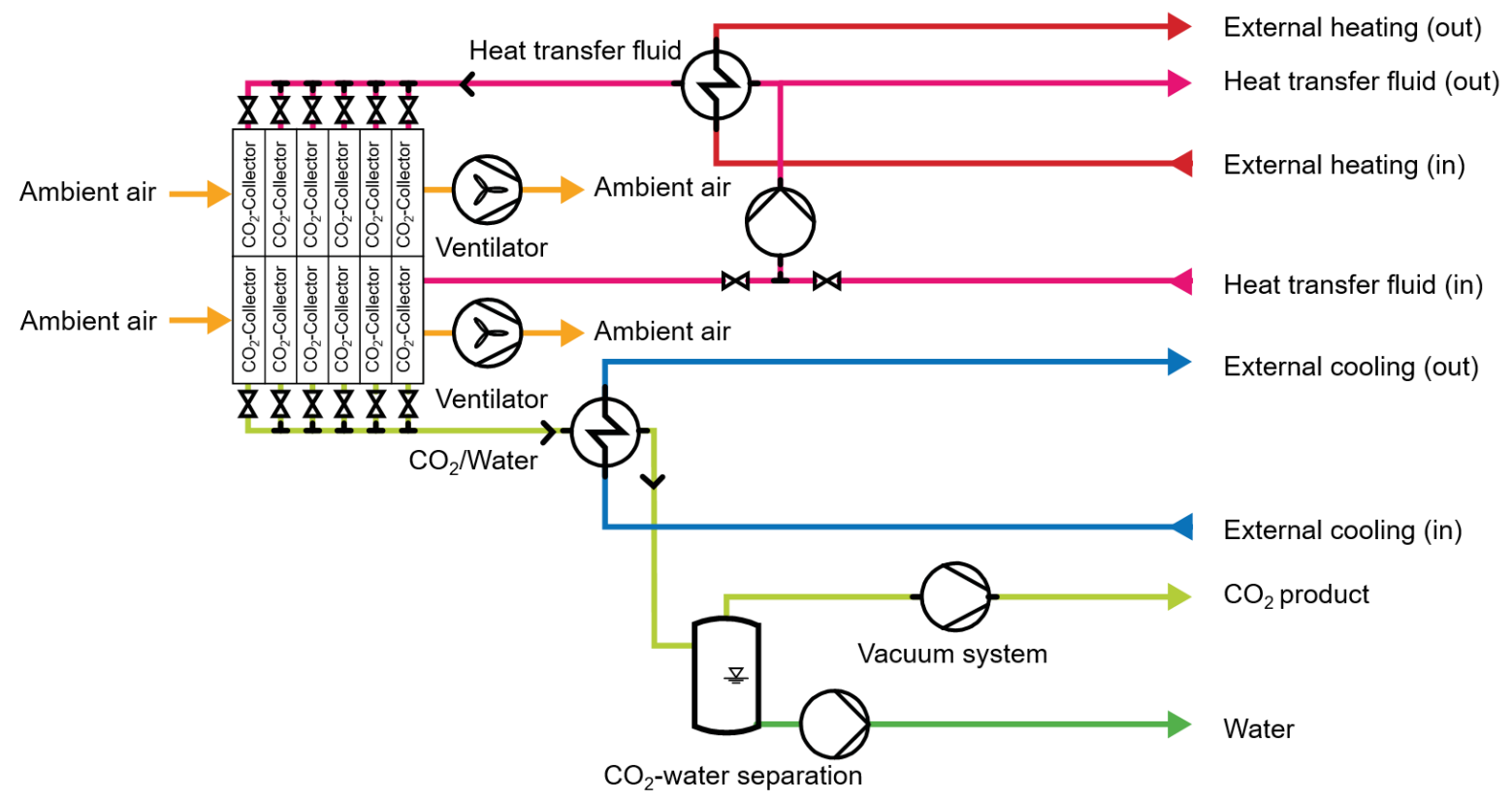

Figure 7: Technical process flowchart of the direct air capture (DAC) process via temperature-vacuum swing adsorption including $12 \mathrm{CO}_{2}$ collectors, heat exchangers for heating and cooling, vacuum system, and water separation unit.

During the adsorption phase, a ventilator drives air through the $\mathrm{CO}_{2}$ collector. $\mathrm{CO}_{2}$ reacts chemically with the adsorbent and binds to it. Some of the adsorbents co-adsorb water depending on weather conditions and humidity in air. ${ }^{35,36,44,45}$ Once adsorption is completed, the desorption process starts for this $\mathrm{CO}_{2}$ collector, which is now closed to the environment. For desorption, heat is delivered to the $\mathrm{CO}_{2}$ collector at a temperature level below $100^{\circ} \mathrm{C}$. Simultaneously, the vacuum system is in operation, removing the $\mathrm{CO}_{2}$ that is released from the adsorbent (Figure 7). Any water is separated from $\mathrm{CO}_{2}$ by cooling the gas stream to induce water condensation. Most of the cooling load can be done with air coolers that are sufficient to remove most of the water and bring $\mathrm{CO}_{2}$ to ambient temperatures. The $\mathrm{CO}_{2}$ is delivered as product at pressures slightly above ambient conditions with a purity above $99-\mathrm{v} / \mathrm{v} \%$. Heat recovery and heat integration strategies are used to reduce the energy consumption of the process. 


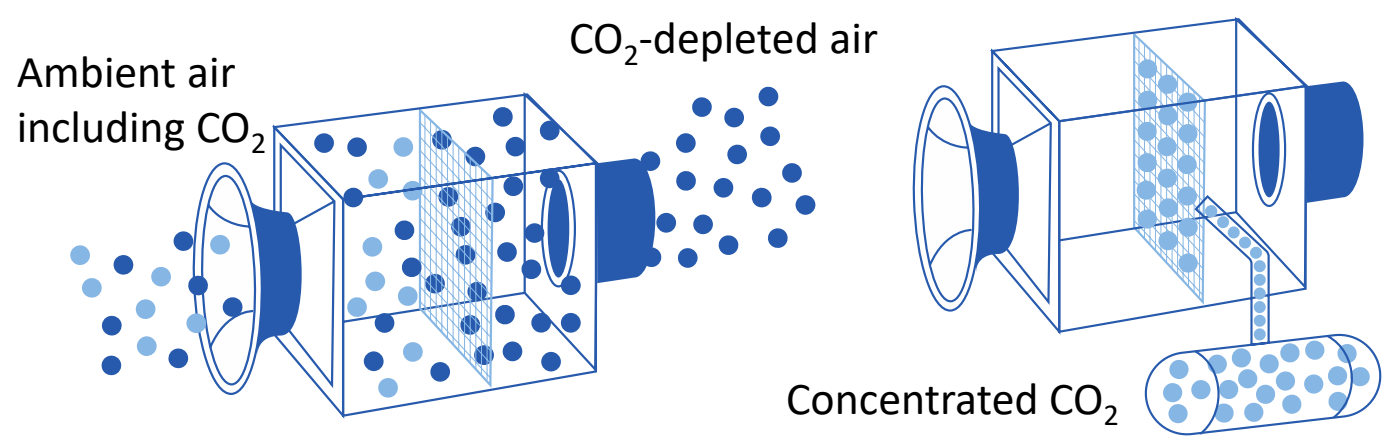

Figure 8: $\mathrm{CO}_{2}$ collector in adsorption (left) and desorption (right) phase. In the adsorption phase, $\mathrm{CO}_{2}$ (light blue) is bound to the adsorbents. In the desorption phase, $\mathrm{CO}_{2}$ is released through vacuum-temperature swing using heat below $100^{\circ} \mathrm{C}$.

\section{Goal and scope definition}

In this paper, we present a comprehensive LCA for direct air capture via temperature-vacuum swing adsorption with six adsorbents. Our LCA study focuses on four goals:

\section{Environmental impacts of captured $\mathrm{CO}_{2}$ from cradle-to-gate and from cradle-to-grave}

We assess the environmental impacts for the captured $\mathrm{CO}_{2}$ from cradle-to-gate, delivering the product $\mathrm{CO}_{2}$. The system boundaries include all environmental impacts due to material and energy supply of the $\mathrm{CO}_{2}$ capture process. In particular, we determine the resulting carbon capture efficiency of DAC (Eq. (1)). However, the cradle-to-gate system boundaries exclude the subsequent application of $\mathrm{CO}_{2}$, which determines if the $\mathrm{CO}_{2}$ is re-emitted or permanently removed from the atmosphere. ${ }^{61,62}$ Therefore, we further expand the system boundary to cradle-to-grave by including two applications for the captured $\mathrm{CO}_{2}$ as a renewable carbon source for synthetic fuels (e.g., methane synthesis) and by assuming geological storage, as in carbon dioxide removal (CDR) applications. To determine the amount of $\mathrm{CO}_{2}$ that is permanently removed from the atmosphere through CDR, we introduce a carbon removal efficiency (Eq. (2)).

\section{Comparing the environmental impacts of six adsorbents}

A wide range of adsorbents are currently discussed for DAC. ${ }^{29}$ These adsorbents differ with respect to the required raw materials, production process, and end-of-life treatment. The environmental impacts of the production and treatment of these adsorbents are often unknown. For this purpose, we compare six promising adsorbent candidates regarding their 
environmental performance..$^{29,41,52}$ The composition and performance of the adsorbents are assessed by the support of Climeworks.

\section{Environmental impacts of the DAC plant construction}

The $\mathrm{CO}_{2}$ capture plant includes the foundation, $\mathrm{CO}_{2}$ collector, process unit, and auxiliaries, which lead to environmental impacts. Thus, we assess the environmental impacts of all materials, including their potential recycling, waste treatment, and final waste disposal to cover the environmental impacts of the entire DAC plant.

\section{Environmental impacts of capturing $1 \%$ of global annual $\mathrm{CO}_{2}$ emissions}

To estimate the environmental impacts of capturing $1 \%$ of the global annual $\mathrm{CO}_{2}$ emissions, we calculate the number of scaled $\mathrm{CO}_{2}$ capture plants and the required energy demand. Additionally, we include the energy for subsequent storage of the captured $\mathrm{CO}_{2}$ in the geological formations to achieve negative emissions. Using global normalization factors ${ }^{59}$, we assess the magnitude of the environmental impacts on a global scale (cf. Environmental impacts and normalization).

\section{System boundaries}

Based on the goals of our LCA study, we distinguish between cradle-to-gate and cradle-tograve system boundaries (Figure 9): The cradle-to-gate system boundary includes all processes associated with capturing $\mathrm{CO}_{2}$ from the atmosphere, i.e., construction of the DAC plant, auxiliaries, energy supply, and adsorbent amounts during the operation of the DAC plant as well as recycling and disposal of all used materials after lifetime. The cradle-to-gate system boundary thus collects all processes up to the delivery of captured $\mathrm{CO}_{2}$.

The cradle-to-gate system boundary, however, excludes the further application of captured $\mathrm{CO}_{2}$ and whether the $\mathrm{CO}_{2}$ is re-emitted or permanently removed from the atmosphere. ${ }^{61,62}$ Therefore, we expand the system boundary to cradle-to-grave considering two applications for the captured $\mathrm{CO}_{2}$ : synthetic fuel production and permanent storage. For synthetic fuel production, we consider synthetic methane via the Sabatier reaction. To cover all life cycle stages, we include the combustion of synthetic methane, entailing the re-emission of $\mathrm{CO}_{2}$. In contrast, geological storage enables a permanent removal of $\mathrm{CO}_{2}$ from the atmosphere to achieve carbon dioxide removal (CDR). 


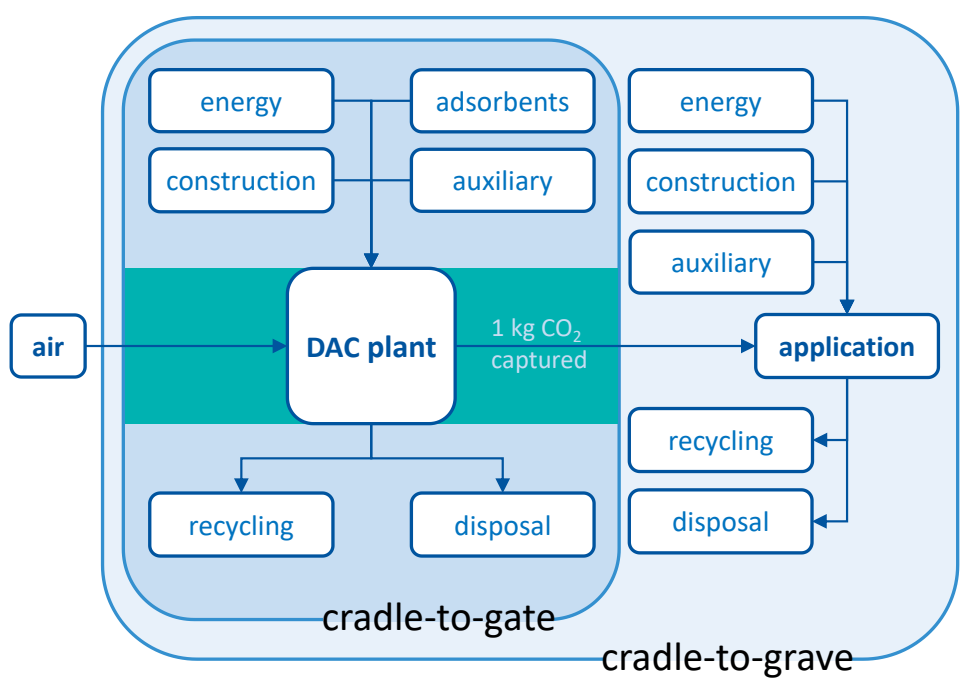

Figure 9: System boundaries: cradle-to-gate boundaries for $\mathrm{CO}_{2}$ capture process only (including recycling, treatment, and final disposal of waste) and cradle-to-grave boundaries including also the subsequent application of the captured $\mathrm{CO}_{2}$. Depending on the application, the $\mathrm{CO}_{2}$ is re-emitted (e.g., synthetic fuels) or permanently removed from the atmosphere (CDR).

\section{Functional unit}

In LCA, the functional unit quantifies the functions of the investigated product and serves as basis for comparison. ${ }^{50,60}$ The function of DAC systems is to capture $\mathrm{CO}_{2}$ from ambient air. Hence, we define " $1 \mathrm{~kg} \mathrm{CO}_{2}$ captured" around ambient conditions with a purity above $99-\mathrm{v} / \mathrm{v} \%$ as functional unit.

In the comparison of the adsorbents, we assume that the same amounts of adsorbents are consumed in the $\mathrm{CO}_{2}$ capture plant over the entire lifetime and provide the environmental impacts also per amount of captured $\mathrm{CO}_{2}$. Similarly, the environmental impacts of the DAC plant are also reported in relation to the functional unit, taking into account the plant lifetime and the amount of $\mathrm{CO}_{2}$ captured.

\section{Environmental impacts and normalization}

The main motivation for capturing $\mathrm{CO}_{2}$ from the atmosphere is the reduction of climate impacts. Our assessment, therefore, focuses on the environmental impact climate change (CC). However, besides climate change, other environmental impacts are associated with the production and disposal of the adsorbents, the DAC plant, and the energy supply for the plant operation. To determine potential environmental trade-offs and to detect potential burdenshifting, we consider 15 further environmental impact categories (Table 2). The environmental impacts are assessed according to the Life Cycle Impact Assessment (LCIA) method Environmental Footprint 2.0 recommended by the European Commission's Joint Research 
Centre. ${ }^{63}$ The recommended environmental impact categories were assessed by the European Commission's Joint Research Centre ${ }^{55}$ and updated regarding their completeness, relevance, robustness, transparency, applicability, acceptance, and suitability for communication. ${ }^{54}$ The results of this assessment are summarized in Table 2 and should be considered interpreting the LCA results.

Table 2: Environmental impact categories considered in this study following the recommendation of the European Commission's Joint Research Centre in the European context according to their quality level. ${ }^{54,55}$

\begin{tabular}{|c|c|c|}
\hline $\begin{array}{l}\text { Quality level I: recommended and } \\
\text { satisfactory }\end{array}$ & $\begin{array}{l}\text { Quality level II: recommended, some } \\
\text { improvements needed }\end{array}$ & $\begin{array}{l}\text { Quality level III: recommended, but } \\
\text { to apply with caution }\end{array}$ \\
\hline Climate change & Acidification, terrestrial and freshwater & Land use \\
\hline Ozone depletion & $\begin{array}{l}\text { Eutrophication, freshwater, terrestrial } \\
\text { and marine }\end{array}$ & Water scarcity \\
\hline \multirow[t]{4}{*}{ Particulate matter } & lonizing radiation & $\begin{array}{l}\text { Resource depletion, fossil, and mineral } \\
\text { and metal }\end{array}$ \\
\hline & Photochemical ozone formation & \\
\hline & $\begin{array}{l}\text { Human toxicity, cancer and non-cancer } \\
\text { effects (II/III) }\end{array}$ & \\
\hline & Ecotoxicity, freshwater (II/III) & \\
\hline
\end{tabular}

However, the interpretation of environmental impacts is not intuitive since the results are expressed in complex units and do not correspond directly to perceptible problems or prevailing threats. ${ }^{64}$ According to the ISO $14044,{ }^{51}$ normalization is an optional procedure to convert environmental impact results into relative contributions compared to an analyzed reference situation. Hence, normalization supports the interpretation of environmental impact results by their classification in terms of relative environmental relevance and provides information on their magnitude. ${ }^{65,66}$ To assess the magnitude of environmental impacts from our LCA on the large-scale use of DAC, we use global normalization factors provided by the European Commission's Joint Research Centre according to the applied LCIA method Environmental Footprint 2.0.59 Global normalization factors represent the total impact of the world in a specific impact category and are used to assess the relevance of the environmental impacts in a global context. 


\section{Carbon capture efficiency and carbon removal efficiency}

To quantify the performance of the direct air capture system from cradle-to-gate, we follow the methodology given by Jonge et al. ${ }^{40}$ and calculate the carbon capture efficiency (\%) as follows:

$$
\eta_{\mathrm{CO}_{2}, \text { capture }}=\frac{m_{\mathrm{CO}_{2, \text { captured }}}-C C_{\text {capture process }}}{m_{C O_{2, \text { captured }}}} \times 100
$$

where $m_{\mathrm{CO}_{2} \text {, captured }}$ represents the amount of $\mathrm{CO}_{2}$ in $\mathrm{kg}$ captured and $C C_{\text {capture process }}$ the climate change (CC) impact due to adsorbent production, construction, end-of-life, and operation of the DAC plant. For a carbon capture efficiency $\eta_{\mathrm{CO}_{2} \text {, capture }}<0$, more $\mathrm{CO}_{2}$ is emitted than captured; while $\eta_{\mathrm{CO}_{2} \text {, capture }}>0$ indicates that more $\mathrm{CO}_{2}$ is captured than emitted. An ideal capture process without any climate impact of its own would achieve a carbon capture efficiency of $100 \%$.

By adding the effort to store the $\mathrm{CO}_{2}$ subsequently, we expand Eq. (1) to calculate the carbon removal efficiency:

$$
\eta_{\mathrm{CO}_{2}, \text { removal }}=\frac{m_{\mathrm{CO}_{2, \text { captured }}}-C C_{\text {capture process }}-C C_{\text {storing process }}}{m_{C O_{2, \text { captured }}}} \times 100
$$

where $C C_{\text {storing process }}$ are the climate impacts induced by storing $\mathrm{CO}_{2}$ in geological reservoirs. A carbon removal efficiency $\eta_{\mathrm{CO}_{2} \text {, removal }}<0$ indicates that more $\mathrm{CO}_{2}$ is emitted than stored, while a $\eta_{\mathrm{CO}_{2} \text {, removal }}>0$ demonstrates that more $\mathrm{CO}_{2}$ is finally removed from the atmosphere than emitted.

\section{Energy scenarios}

Environmental impacts of DAC systems are, to large extent, determined by energy requirements. The electricity consumption of the DAC plant is mainly caused by the operation of the fan that passes the air through the $\mathrm{CO}_{2}$-collector and depends on the pressure drop. The pressure drop through the $\mathrm{CO}_{2}$-collector is determined by the design of the flow structures. By adjusting the bed thickness for each adsorbent in the flow structure, the pressure drop of 
the $\mathrm{CO}_{2}$-collector and thus the power consumption is maintained similar for adsorption with the analyzed adsorbents. In addition, electricity is required to run the vacuum system and pumps.

Thermal energy is needed to heat the collector, i.e., the adsorbent and metals in the collector, to initiate the desorption of $\mathrm{CO}_{2}$. The thermal energy demand is determined, inter alia, by the heat capacities of the adsorbents, adsorption enthalpies, enthalpies of the air constituents, humidity as well as water absorption and the surface area of supports. However, the operation of the plant would be optimized for each adsorbent regarding heat recovery and management. Based on experience by Climeworks, the energy requirements for all considered adsorbents are within the specified energy scenarios.

We consider two energy scenarios: a today and future scenario (Table 3). For the today scenario, we use values for electricity and heat, which have been measured at the first-of-kind commercial DAC plant operating by Climeworks. The future scenario is based on the predicted energy targets of Climeworks, taking into account heat recovery and optimization potential, which has been estimated based on tests conducted at lab-scale. The used energy requirements are in line with other scenarios. ${ }^{43}$

Table 3: Energy requirements for the DAC plant based on measured data (today) and predicted energy targets of Climeworks, estimated based on heat recovery and optimization potential, per $\mathrm{kg} \mathrm{CO}_{2}$ captured (future). Heat supply below $100^{\circ} \mathrm{C}$ is required. Applied electricity and heat sources are specified in Section Energy Scenarios.

\begin{tabular}{lccc}
\hline \hline Process & Amount & Unit \\
& today & future & $\mathrm{kWh}$ \\
\hline Electricity supply & 0.7 & 0.5 & $\mathrm{MJ}$ \\
Heat supply & 11.9 & 5.4 & \\
\hline \hline
\end{tabular}

For the electricity supply, we consider the following scenarios (Table 4): environmentally burden-free surplus power, electricity from wind power and photovoltaics, representative electricity grid mixes for several countries today from the LCA database and global forecasts based on 'beyond $2^{\circ} \mathrm{C}$ scenario' of the IEA for 2030 and $2050 .{ }^{67}$ For a detailed description, please refer to Supplementary Table 12 and Table 13).

Since direct air capture requires low-temperature heat below $100^{\circ} \mathrm{C}$, one scenario considers the use of waste heat, e.g., from the chemical industry or incineration processes, which is assumed to be environmentally burden-free (Table 4). For decentralized locations where no waste heat is available, we consider a heat pump (Table 4). The coefficient of performance $C O P_{H P}$ for the heat pump is calculated according to: 


$$
C O P_{H P}=\frac{T_{\text {out }}}{T_{\text {out }}-T_{\text {in }}} \times \eta_{\text {exergy }} \text {, }
$$

where $T_{i n}$ and $T_{\text {out }}$ are the inlet and outlet temperature. $T_{\text {in }}$ represents the ambient temperature and is assumed to be $15^{\circ} \mathrm{C}$ on average, while $T_{\text {out }}$ is the required maximum temperature of $100^{\circ} \mathrm{C} . \eta_{\text {exergy }}$ represents the exergetic efficiency and generally varies for heat pumps between $50-70 \%{ }^{68,69}$ Here, we use an average value exergetic efficiency of $\eta_{\text {exergy }}=60 \%$. Based on these assumptions, we obtain a $C O P_{H P}$ of 2.51 for the considered heat pump system, which is in range of other installed large-scale heat pump systems. ${ }^{70,71}$

Additionally, we consider the local energy supply conditions for two locations where Climeworks is currently operating: Hellisheiði (Iceland) and Hinwil (Switzerland). For Hellisheiði, we use electricity and heat from geothermal energy in Iceland. According to Karlsdóttir et al. ${ }^{72}$, the geothermal efficiency of the plant in Hellisheiði is between $11-37 \%$ depending on how the energy content of the fluid is defined. The $\mathrm{LCl}$ data for the geothermal plant construction is based on Karlsdottir et al. ${ }^{73}$, while the direct emissions are updated to 2018 by the Reykjavik Energy Group ${ }^{74}$ (cf. Supplementary Table 14 and Table 16). Since the LCl data for the construction of the geothermal plant do not include end-of-life treatment, we use the same assumptions as for the DAC plant (cf. Supplementary Table 15 and Table 17). 
Table 4: Energy supply scenarios for the DAC plant including, the climate impacts. Heat supply is required below $100^{\circ} \mathrm{C}$. Heat and electricity for the plant in Hellisheiði are supplied by geothermal energy. The plant in Hinwil uses electricity and waste heat from an incineration plant. Climate impacts of the electricity supply from the database $\mathrm{GaBi}^{75}$ are published with permission from the Thinkstep AG (DB version 8.7 SP 39).

\begin{tabular}{|c|c|c|c|}
\hline Process & Climate impact & Unit & Reference \\
\hline \multicolumn{4}{|l|}{ Electricity supply } \\
\hline Surplus & Assumed to be burden-free & $\mathrm{gCO}_{2 \mathrm{e}}$ per kWh & \\
\hline Wind & 10 & $\mathrm{gCO}_{2 \mathrm{e}}$ per kWh & $\mathrm{GaBi}^{75}$ \\
\hline Photovoltaics & 83 & $\mathrm{gCO}_{2 \mathrm{e}}$ per kWh & $\mathrm{GaBi}^{75}$ \\
\hline $\begin{array}{l}\text { Country-specific grid mixes } \\
\text { today }\end{array}$ & $19-578$ & $\mathrm{gCO}_{2 \mathrm{e}}$ per kWh & $\mathrm{GaBi}^{75}$ \\
\hline Global average 2030 & 277 & $\mathrm{gCO}_{2 \mathrm{e}}$ per kWh & $\begin{array}{l}\text { Based on 'beyond } 2^{\circ} \mathrm{C} \text { scenario' of } \\
\text { the IEA }\end{array}$ \\
\hline Global average 2050 & 81 & $\mathrm{gCO}_{2 \mathrm{e}}$ per kWh & $\begin{array}{l}\text { Based on 'beyond } 2^{\circ} \mathrm{C} \text { scenario' of } \\
\text { the IEA }{ }^{67}\end{array}$ \\
\hline Hinwil (Switzerland) & 166 & $\mathrm{gCO}_{2 \mathrm{e}}$ per kWh & Based on $\mathrm{GaBi}^{75}$ \\
\hline Hellisheiði (Iceland) & 11 & $\mathrm{gCO}_{2 \mathrm{e}}$ per kWh & $\begin{array}{l}\text { Based on Karlsdottir et al. }{ }^{73} \text { and } \\
\text { Reykjavik Energy Group }{ }^{74}\end{array}$ \\
\hline \multicolumn{4}{|l|}{ Heat supply } \\
\hline Waste heat & Assumed to be burden-free & $\mathrm{gCO}_{2 \mathrm{e}}$ per $\mathrm{MJ}$ & \\
\hline Heat pump & $\begin{array}{l}\text { Depending on electricity } \\
\text { supply }\end{array}$ & $\mathrm{gCO}_{2 \mathrm{e}}$ per MJ & \\
\hline Hellisheiði (Iceland) & 3 & $\mathrm{gCO}_{2 \mathrm{e}}$ per $\mathrm{MJ}$ & $\begin{array}{l}\text { Based on Karlsdottir et al. }{ }^{73} \text { and } \\
\text { Reykjavik Energy Group }\end{array}$ \\
\hline
\end{tabular}

For the plant in Hinwil, we consider electricity and waste heat (below $100^{\circ} \mathrm{C}$ ) from municipal waste incineration. However, waste incineration plants serve primarily to treat waste, while electricity and heat are co-produced. Thus, waste incineration leads to the problem of multifunctionality. ${ }^{76}$ For this purpose, we assume that the electricity co-produced from incineration is no longer fed into the Swiss grid but consumed by the DAC plant. Hence, the conventional electricity production in the Swiss grid has to be expanded due to the consumed electricity for the DAC. Thus, the electricity consumed obtains the environmental burdens from the Swiss grid mix. This choice represents an average value and alternative options to solve multifunctionality might alter LCA results. For this purpose, we perform a sensitivity study of alternative options to solve multifunctionality on the derived LCA results (Supplementary Table 17 and Table 28).

\section{Applications for the captured $\mathrm{CO}_{2}$}

For the captured $\mathrm{CO}_{2}$, we consider two applications: (1) the utilization of $\mathrm{CO}_{2}$ as a renewable carbon source for fuels and (2) the geological storage of $\mathrm{CO}_{2}$ enabling, carbon dioxide removal. For the $\mathrm{CO}_{2}$ utilization process, we consider the production of synthetic methane $\left(\mathrm{CH}_{4}\right)$, also known as 'Power-to-Gas'. ${ }^{77,78}$ In the Power-to-Gas process, renewable electricity is used to produce hydrogen $\left(\mathrm{H}_{2}\right)$ via water electrolysis. ${ }^{77,79}$ The hydrogen is converted with the captured 
$\mathrm{CO}_{2}$ to produce synthetic methane via the Sabatier reaction. ${ }^{56}$ Synthetic methane can substitute natural gas using the existing distribution infrastructure. ${ }^{80}$ At the same time, synthetic methane provides the opportunity to store intermittent renewable energy by flexible operation of the electrolyzer. ${ }^{77}$

The data for synthetic methane production is based on the process from Bongartz et al. ${ }^{80}$. Due to the highly exothermic Sabatier reaction, only a small portion of the generated heat is required internally in the methanation process. ${ }^{80}$ The surplus heat can be directly integrated into the DAC process, thereby covering the entire heat demand if the plants are co-located. If waste heat from other sources is available, the surplus heat from the synthetic methane process could also be used to generate superheated steam for electricity generation, however, such uses are not considered in this work.

To cover the full carbon life cycle for synthetic methane, we include the environmental impacts for the combustion of methane at the end of life. The actual use of methane, e.g., electricity production, is neglected since the main focus of our study is the comparison to fossil methane such that the use phase is identical and drops out of the comparison. Mass and energy balances for the synthetic methane process are in the Supplementary Table 19. The construction of the methanation plant is neglected due to the lack of data.

For $\mathrm{CO}_{2}$ storage, $\mathrm{CO}_{2}$ is compressed and injected into a geological formation such as depleted oil and gas reservoirs, saline aquifers, and deep coal seams. ${ }^{81,82}$ The injection of $\mathrm{CO}_{2}$ requires high pressures of around 110-150 bar. $^{83,84}$ We assume an 8-stage compressor and intercooling to $40^{\circ} \mathrm{C}$ to achieve an injection pressure of 150 bar. The required pressure could be reduced to approximately 12 bar by using mineralization to store $\mathrm{CO}_{2}$ as currently conducted at the DAC plant in Hellisheiði (Iceland), ${ }^{85}$ but this route is not considered in our study. Instead, the compression to 150 bar is used as conservative assumption. For a detailed description, please refer to Supplementary Table 20. We assume storing $\mathrm{CO}_{2}$ in a depleted gas reservoir with infrastructure from former gas or oil production that can be used for injection and require no additional infrastructure for the storage process.

\section{Capturing $1 \%$ of global annual $\mathrm{CO}_{2}$ emissions}

For the goal to capture $1 \%$ of the global annual $\mathrm{CO}_{2}$ emissions, we evaluate the required energy demand to capture $\mathrm{CO}_{2}$ and the numbers of capture plants needed. Herein, we assume a design for a future large-scale plant with a capacity of $100 \mathrm{kt} / \mathrm{a}$. As electricity source, we 
assume wind energy, which is currently the renewable energy source with a high expansion potential ${ }^{86}$ and a low carbon footprint, ${ }^{75}$ thus provides a best-case.

The raw material for the capture plants and their energy requirements are compared to the actual global market sizes of the corresponding raw materials and a forecast of the electricity generation in $2030^{67}$ (cf. Supplementary Table 21) to provide a context for the demands. The estimated environmental impacts are normalized using global normalization factors according to the method Environmental Footprint 2.0 to quantify the order of magnitude of the environmental impacts. The normalized results are presented from cradle-to-gate and cradleto-grave.

\section{Acknowledgements}

The authors gratefully acknowledge funding by the German Federal Ministry of Education and Research (BMBF) within the Kopernikus Project P2X: flexible use of renewable resources exploration, validation and implementation of 'Power-to-X' concepts. We thank our partners from Climeworks, who provided data, insight, and expertise in their technology that greatly assisted our research. We thank Leif Kroeger and Kai Leonhard for the valuable discussions on reaction kinetics and thermochemistry, and Dominik Bongartz for conducting the process simulations on heat integration of DAC and synthetic fuel production. We further thank Verena Beckert, Lukas Dörpinghaus, Niklas Groll, Felicitas Pellengahr, and Nergiz Tigu for their technical support.

\section{References}

1. J. Tollefson, Nature, 2019(537), 324.

2. C. Le Quéré, R. B. Jackson, M. W. Jones, A. J. P. Smith, S. Abernethy, R. M. Andrew, A. J. De-Gol, D. R. Willis, Y. Shan, J. G. Canadell, P. Friedlingstein, F. Creutzig and G. P. Peters, Nature Climate Change, 2020.

3. UNFCCC, United Nations Framework Convention on Climate Change, Report of the Conference of the Parties on its Twenty-First Session: Decision 1/CP.21, Held in Paris from 30 November to 13 December 2015, 2015.

4. IPCC, Intergovernmental Panel on Climate Change, Special Report: Global Warming of $1.5^{\circ} \mathrm{C}, 2018$.

5. J. C. Minx, W. F. Lamb, M. W. Callaghan, L. Bornmann and S. Fuss, Environ. Res. Lett., 2017, 12(3), 35007.

6. T. Gasser, C. Guivarch, K. Tachiiri, C. D. Jones and P. Ciais, Nat. Commun., 2015, 6, 7958 EP -. 
7. P. Smith, S. J. Davis, F. Creutzig, S. Fuss, J. Minx, B. Gabrielle, E. Kato, R. B. Jackson, A. Cowie, E. Kriegler, D. P. van Vuuren, J. Rogelj, P. Ciais, J. Milne, J. G. Canadell, D. McCollum, G. Peters, R. Andrew, V. Krey, G. Shrestha, P. Friedlingstein, T. Gasser, A. Grübler, W. K. Heidug, M. Jonas, C. D. Jones, F. Kraxner, E. Littleton, J. Lowe, J. R. Moreira, N. Nakicenovic, M. Obersteiner, A. Patwardhan, M. Rogner, E. Rubin, A. Sharifi, A. Torvanger, Y. Yamagata, J. Edmonds and C. Yongsung, Nat. Clim. Change., 2016, 6(1), 42.

8. J. Rogelj, A. Popp, K. V. Calvin, G. Luderer, J. Emmerling, D. Gernaat, S. Fujimori, J. Strefler, T. Hasegawa, G. Marangoni, V. Krey, E. Kriegler, K. Riahi, D. P. van Vuuren, J. Doelman, L. Drouet, J. Edmonds, O. Fricko, M. Harmsen, P. Havlík, F. Humpenöder, E. Stehfest and M. Tavoni, Nat. Clim. Change., 2018, 8(4), 325.

9. P. Goglio, A. G. Williams, N. Balta-Ozkan, N.R.P. Harris, P. Williamson, D. Huisingh, Z. Zhang and M. Tavoni, Journal of Cleaner Production, 2020, 244, 118896.

10. K. S. Lackner, Eur. Phys. J. Spec. Top., 2009, 176(1), 93.

11. F. M. Brethomé, N. J. Williams, C. A. Seipp, M. K. Kidder and R. Custelcean, Nature Energy, 2018, 3(7), 553.

12. R. Socolow, M. Desmond, R. Aines, J. Blackstock, O. Bolland, T. Kaarsberg, N. Lewis, M. Mazzotti, A. Pfeffer, K. Sawyer, Siirola, Jeffrey, B. Smit and J. Wilcox, Direct Air Capture of CO2 with Chemicals: A Technology Assessment for the APS Panel on Public Affairs, 2011.

13. I. Gunnarsson, E. S. Aradóttir, E. H. Oelkers, D. E. Clark, M. Pór Arnarson, B. Sigfússon, S. Ó. Snæbjörnsdóttir, J. M. Matter, M. Stute, B. M. Júlíusson and S. R. Gíslason, Int J Greenh Gas Con, 2018 79, 117.

14. J. M. Matter, M. Stute, S. Ó. Snæbjörnsdottir, E. H. Oelkers, S. R. Gislason, E. S. Aradottir, B. Sigfusson, I. Gunnarsson, H. Sigurdardottir, E. Gunnlaugsson, G. Axelsson, H. A. Alfredsson, D. Wolff-Boenisch, K. Mesfin, Taya, Diana Fernandez de la Reguera, J. Hall, K. Dideriksen and W. S. Broecker, Science, 2016, 352(6291), 1312.

15. C. van der Giesen, R. Kleijn and G. J. Kramer, Environ. Sci. Technol., 2014, 48(12), 7111.

16. M. Matzen and Y. Demirel, J Clean Prod, 2016, 139, 1068.

17. V. Uusitalo, S. Vaisanen, E. Inkeri and R. Soukka, Energy Convers. Manag., 2017, 134, 125.

18. W. Schakel, G. Oreggioni, B. Singh, A. Stromman and A. Ramirez, J CO2 Util, 2016, 16, 138.

19. S. Deutz, D. Bongartz, B. Heuser, A. Kätelhön, L. Schulze Langenhorst, A. Omari, M. Walters, J. Klankermayer, W. Leitner, A. Mitsos, S. Pischinger and A. Bardow, Energy Environ. Sci., 2018, $11(2), 331$.

20. C. M. Liu, N. K. Sandhu, S. T. McCoy and J. A. Bergerson, Sustainable Energy Fue/s, 2020, 4(6), 3129.

21. R. Meys, A. Kätelhön and A. Bardow, Green Chem, 2019, 21(12), 3334.

22. N. von der Assen and A. Bardow, Green Chem, 2014, 16(6), 3272.

23. J. Artz, T. E. Müller, K. Thenert, J. Kleinekorte, R. Meys, A. Sternberg, A. Bardow and W. Leitner, Chem. Rev., 2018, 118(2), 434.

24. A. Kätelhön, R. Meys, S. Deutz, S. Suh and A. Bardow, PANS, 2019, 116(23), 11187.

25. H. Ostovari, A. Sternberg and A. Bardow, Sustain. Energy Fuels, 2020, (accepted).

26. K. E. Kelly, G. D. Silcox, A. F. Sarofim and D. W. Pershing, Int J of Greenh Gas Con, 2011, 5(6), 1587.

27. E. Nduagu, J. Bergerson and R. Zevenhoven, Energy Convers. Manag., 2012, 55, 116. 
28. B. Smit, J. A. Reimer, C. M. Oldenburg and I. C. Bourg, Introduction to Carbon Capture and Sequestration, Imperial College Press, 2014.

29. E. S. Sanz-Pérez, C. R. Murdock, S. A. Didas and C. W. Jones, Chem. Rev., 2016, 116(19), 11840.

30. N. McQueen, P. Psarras, H. Pilorgé, S. Liguori, J. He, M. Yuan, C. M. Woodall, K. Kian, L. Pierpoint, J. Jurewicz, J. M. Lucas, R. Jacobson, N. Deich and J. Wilcox, Environ. Sci. Technol., 2020, 54(12), 7542.

31. V. Nikulshina, M. E. Gálvez and A. Steinfeld, Chem Eng J., 2007, 129(1), 75.

32. V. Nikulshina, C. Gebald and A. Steinfeld, Chem Eng J., 2009, 146(2), 244.

33. H. Azarabadi and K. S. Lackner, Appl. Energy, 2019, 250, 959.

34. W. Chaikittisilp, H.-J. Kim and C. W. Jones, Energy Fuels, 2011, 25(11), 5528.

35. C. Gebald, J. A. Wurzbacher, A. Borgschulte, T. Zimmermann and A. Steinfeld, Environ. Sci. Technol., 2014, 48(4), 2497.

36. C. Gebald, J. A. Wurzbacher, P. Tingaut and A. Steinfeld, Environ. Sci. Technol., 2013, 47(17), 10063.

37. C. Gebald, J. A. Wurzbacher, P. Tingaut, T. Zimmermann and A. Steinfeld, Environ. Sci. Technol., 2011, 45(20), 9101

38. T. M. McDonald, J. A. Mason, X. Kong, E. D. Bloch, D. Gygi, A. Dani, V. Crocellà, F. Giordanino, S. O. Odoh, W. S. Drisdell, B. Vlaisavljevich, A. L. Dzubak, R. Poloni, S. K. Schnell, N. Planas, K. Lee, T. Pascal, L. F. Wan, D. Prendergast, J. B. Neaton, B. Smit, J. B. Kortright, L. Gagliardi, S. Bordiga, J. A. Reimer and J. R. Long, Nature, 2015, 519, 303 EP -.

39. D. W. Keith, G. Holmes, D. St. Angelo and K. Heidel, Joule, 2018, 2(8), 1573.

40. M. M.J. de Jonge, J. Daemen, J. M. Loriaux, Z. J.N. Steinmann and M. A.J. Huijbregts, Int J Greenh Gas Con, 2019, 80, 25.

41. A. Goeppert, M. Czaun, G. K. Surya Prakash and G. A. Olah, Energy Environ. Sci., 2012, 5(7), 7833.

42. J. A. Wurzbacher, C. Gebald and A. Steinfeld, Energy Environ. Sci., 2011, 4(9), 3584.

43. M. Fasihi, O. Efimova and C. Breyer, J. Clean. Prod., 2019, 224, 957.

44. J. A. Wurzbacher, C. Gebald, S. Brunner and A. Steinfeld, Chem Eng J., 2016, 283, 1329.

45. J. A. Wurzbacher, C. Gebald, N. Piatkowski and A. Steinfeld, Environ. Sci. Technol., 2012, 46(16), 9191.

46. N. R. Stuckert and R. T. Yang, Environ. Sci. Technol., 2011, 45(23), 10257.

47. C. van der Giesen, C. J. Meinrenken, R. Kleijn, B. Sprecher, K. S. Lackner and G. J. Kramer, Environ. Sci. Technol., 2017, 51(2), 1024.

48. X. Zhang, C. Bauer, C. L. Mutel and K. Volkart, Applied Energy, 2017, 190, 326.

49. G. Realmonte, L. Drouet, A. Gambhir, J. Glynn, A. Hawkes, A. C. Köberle and M. Tavoni, Nat Commun, 2019, 10(1), 3277.

50. ISO 14040, International Organization for Standardization. Environmental Management - Life Cycle Assessment: Principles and Framework, 2006.

51. ISO 14044, International Organization for Standardization. Environmental management — Life cycle assessment: Requirements and guidelines, 2006. 
52. S.-Y. Lee and S.-J. Park, J Ind Eng Chem, 2015, 23, 1.

53. Climeworks, Press release: Climeworks raises CHF 30.5M(USD 30.8M)to commercialize carbon dioxide removal technology, 2018.

54. JRC, European Commission - Joint Research Centre - Institute of Environment and Sustainability, Supporting information to the characterisation factors of recommended EF Life Cycle Impact Assessment method: New models and differences with ILCD, 2018.

55. JRC, European Commission - Joint Research Centre - Institute of Environment and Sustainability, The International Reference Life Cycle Data System (ILCD) Handbook: Recommendations for Life Cycle Impact Assessment in the European context from the European Commission, Publications Office of the European Union, Luxembourg, 2011.

56. A. Sternberg and A. Bardow, Energy Environ. Sci., 2015, 8(2), 389.

57. UNCCD \& IEA, United Nations Convention to Combat Desertification and International Renewable Energy Agency, Global land outlook: Energy and land use, 2017.

58. NAS, National Academies of Sciences, Engineering, and Medicine. Negative Emissions Technologies and Reliable Sequestration: A Research Agenda, Washington, DC, 2018.

59. S. Sala, E. Crenna, M. Secchi and R. Pant, Global normalisation factors for the Environmental Footprint and Life Cycle Assessment, 2017.

60. JRC, European Commission - Joint Research Centre - Institute of Environment and Sustainability, The International Reference Life Cycle Data System (ILCD) Handbook: General guide for Life Cycle Assessment - Detailed guidance, Publications Office of the European Union, Luxembourg, 2010.

61. S. E. Tanzer and A. Ramírez, Energy Environ. Sci., 2019, 12(4), 1210.

62. L. J. Müller, A. Kätelhön, M. Bachmann, A. Zimmermann, A. Sternberg and A. Bardow, Front. Energy Res., 2020, 8, 15.

63. JRC, European Commission - Joint Research Centre - Institute of Environment and Sustainability, Product Environmental Footprint Category Rules Guidance: Version 6.3 - May 2018, 2018.

64. A. Wegener Sleeswijk, L. F.C.M. van Oers, J. B. Guinée, J. Struijs and M. A. J. Huijbregts, Sci Total Environ, 2008, 390(1), 227.

65. E. Crenna, M. Secchi, L. Benini and S. Sala, Int J LCA, 2019, 24(10), 1851.

66. M. Pizzol, A. Laurent, S. Sala, B. Weidema, F. Verones and C. Koffler, Int J LCA, 2017, 22(6), 853.

67. IEA, International Energy Agency, Energy Technology Perspectives 2017: Catalysing Energy Technology Transformations, 2017.

68. H. Esen, M. Inalli, M. Esen and K. Pihtili, Build. Environ., 2007, 42(10), 3606.

69. O. Ozgener and A. Hepbasli, Energ Buildings, 2005, 37(1), 101.

70. H. Averfalk, P. Ingvarsson, U. Persson, M. Gong and S. Werner, Renew Sust Energ Rev, 2017, 79, 1275.

71. A. David, B. V. Mathiesen, H. Averfalk, S. Werner and H. Lund, Energies, 2017, 10(4), 578.

72. M. R. Karlsdóttir, O. P. Palsson and H. Palsson, LCA of combined heat and power production at Hellisheiði geothermal power plant with focus on primary energy efficiency, 2010.

73. M. R. Karlsdóttir, Ó. P. Pálsson, H. Pálsson and L. Maya-Drysdale, Int J LCA, 2015, 20(4), 503. 
74. Reykjavik Energy Group, Environmental Data - Emissions from Hellisheiði: Reykjavik: Internal Reykjavik Energy Group Report: unpublished, Reykjavik, 2019.

75. GaBi, GaBi 9.2.0.58: Software-System and Database for Life Cycle Engineering, DB 8.7 - SP 39, thinkstep AG, Leinfelden-Echterdingen, Germany, 2019.

76. T. Ekvall and B. P. Weidema, Int J LCA, 2004, 9(3), 161.

77. A. Sternberg and A. Bardow, ACS Sustain. Chem. Eng., 2016, 4(8), 4156.

78. M. Götz, J. Lefebvre, F. Mörs, A. McDaniel Koch, F. Graf, S. Bajohr, R. Reimert and T. Kolb, Renew Energy, 2016, 85, 1371.

79. A. Sternberg, C. M. Jens and A. Bardow, Green Chem, 2017, 19(9), 2244.

80. D. Bongartz, L. Doré, K. Eichler, T. Grube, B. Heuser, L. E. Hombach, M. Robinius, S. Pischinger, D. Stolten, G. Walther and A. Mitsos, Appl. Energy, 2018, 231, 757.

81. R. M. Cuéllar-Franca and A. Azapagic, J CO2 Util, 2015, 9, 82.

82. M. E. Boot-Handford, J. C. Abanades, E. J. Anthony, M. J. Blunt, S. Brandani, N. Mac Dowell, J. R. Fernández, M.-C. Ferrari, R. Gross, J. P. Hallett, R. S. Haszeldine, P. Heptonstall, A. Lyngfelt, Z. Makuch, E. Mangano, R. T. J. Porter, M. Pourkashanian, G. T. Rochelle, N. Shah, J. G. Yao and P. S. Fennell, Energy Environ. Sci., 2014, 7(1), 130.

83. J. Koornneef, T. van Keulen, A. Faaij and W. Turkenburg, Int J Greenh Gas Con, 2008, 2(4), 448.

84. M. Pehnt and J. Henkel, Int J Greenh Gas Con, 2009, 3(1), 49.

85. N. Andersen, B. Sigfússon, Dór Arnarson, Magnús, Ósk Snæbjörnsdóttir and Sandra, Proceedings World Geothermal Congress 2020 Reykjavik, Iceland, 2020.

86. IEA, International Energy Agency, Global Energy \& CO2 Status Report 2017, 2018. 